\title{
Pamięć lekturowa a tożsamość czytelnika na przykładzie powieści Tajemniczy płomień królowej Loany Umberta Eco
}

Przedmiotem artykułu jest bibliologiczna refleksja nad powieścią Umberta Eco. Jej fabuła jest pretekstem do postawienia pytań na temat tożsamości czytelnika. Czy człowiek jest sumą przeczytanych tekstów? Jakie znaczenie dla budowania własnego ja mają lektury? W artykule przeanalizowano, czy i jak realizacja książkowa tekstu wpływa na jego odbiór, biorąc pod uwagę miejsce, jakie literatura zajmuje w kulturze masowej. Przedstawiono także rolę materiału ilustracyjnego; omówiono sposób funkcjonowania ilustracji w tekście oraz ich funkcje i znaczenie dla fabuły. Przedstawiono powieść jako przykład książki hipertekstowej.

Słowa kluczowe: Umberto Eco, kultura masowa, tożsamość czytelnika, książka ilustrowana, książka hipertekstowa

W 2004 roku we włoskim wydawnictwie Bompiani ukazała się piąta powieść Umberta Eco. Rok później książka Tajemniczy płomień królowej Loany (wł. La misteriosa fiamma della regina Loana) pojawiła się także na półkach polskich księgarń'.

* Mgr, Uniwersytet Wrocławski, Wydział Filologiczny, Instytut Informacji Naukowej i Bibliotekoznawstwa, pl. Uniwersytecki 9/13, 50-137 Wrocław; e-mail: anna.lubinska@uwr.edu.pl

1 U. Eco, Tajemniczy płomień królowej Loany, przeł. K. Żaboklicki, Noir sur Blanc, Warszawa 2005. 
Tekst, zarówno polski, jak i włoski, został wzbogacony licznymi reprodukcjami okładek książek, czasopism i komiksów, książkowych ilustracji, plakatów i innych materiałów graficznych, uzupełniających historię głównego bohatera, co tłumaczy nadany przed autora podtytuł książki: Powieść ilustrowana.

W swojej powieści Umberto Eco porusza problematykę literatury rozumianej jako medium pamięci, zastanawiając się, w jaki sposób wytwory pamięci zbiorowej wpływają na pamięć indywidualną. Przekonuje, że chociaż pamięć zbiorową, a także indywidualną, tworzą dziś przede wszystkim wytwory kultury masowej, do pełnego obrazu siebie potrzebujemy czegoś unikatowego, wyjątkowego tylko dla nas. Swoją powieścią udowadnia, że o ile tożsamość człowieka tworzą teksty, równie ważna jest ich materialna realizacja oraz emocje, jakie wywołują.

\section{Pamięć z papieru}

Narratorem powieści jest sześćdziesięcioletni antykwariusz Giambattista Bodoni, nazywany przez bliskich Jambo. Czytelnik poznaje go, kiedy ten budzi się po wypadku i dowiaduje, że stracił pamięć - jednak tylko tę epizodyczną (autobiograficzną), a więc dotyczącą osobistych doświadczeń i własnej tożsamości ${ }^{2}$. Bohater nie wie, jak się nazywa, ile ma lat, ani który jest rok; nie pamięta też żadnych wydarzeń, w których uczestniczył. W jego wspomnieniach pozostaje natomiast to, co tworzy pamięć semantyczną - encyklopedyczną i erudycyjną - związaną z wiedzą ogólną i zdobytym wykształceniem, i automatyczną ${ }^{3}$.

$\mathrm{W}$ trudnej sytuacji pozbawienia własnego ja bohater jest zdany na posługiwanie się cudzymi słowami. Na myśl bezustannie przychodzą mu cytaty z przeczytanych książek; mówi słowami słynnych poetów i pisarzy, nie potrafi jednak sam określić, kim jest - jakie są jego przyzwyczajenia, pasje i umiejętności. Na pytanie o to, jak się nazywa, odpowiada jak bohater Przygód Arthura Gordona Pyma (ang. Narrative of Arthur Gordon Pym of Nantucket, 1838) Edgara Allana Poe: „Nazywam się Arthur Gordon Pym", a dowiadując się, że jest obecnie kwiecień, przypomina sobie słowa z Ziemi jałowej (ang. The Waste Land, 1922) Thomasa S. Eliota: „najokrutniejszy miesiąc to kwiecień”. „Cytaty są dla mnie jedynymi latarniami we mgle", wyznaje antykwariusz.

2 Ten rodzaj pamięci odpowiada za przechowywanie materiału dotyczącego indywidualnej historii życia danej jednostki. Zob. T. Maruszewski, Pamięć autobiograficzna, Gdańskie Wydawnictwo Psychologiczne, Gdańsk 2005, s. 18.

3 Jest to tzw. pamięć ciała, dzięki której takie czynności jak mycie zębów czy jazda samochodem nie sprawiają bohaterowi problemów.

4 U. Eco, dz. cyt., s. 12.

5 Tamże, s. 13.

6 Tamże, s. 71. 
Jambo doskonale pamięta bohaterów literackich, nie rozpoznaje jednak bliskich osób - żona, dzieci i wnuki są mu bardziej obcy niż postacie znane z kart książek. Charakter relacji ze spotykanymi ludźmi - jak chociażby z jego współpracownicą, polską emigrantką Sybillą Jasnorzewską ${ }^{7}$ - pozostaje dla niego niejasny. Wie wiele o otaczającym go świecie, lecz nie ma pojęcia, jaki wpływ poszczególne wydarzenia wywarły na jego życie, jakie są jego poglądy i przekonania. Pamięć semantyczna, to, czym dysponuje bohater, jest po prostu wiedzą o świecie, niemieszczącą znaczeń, lecz operującą wyłącznie faktami mającymi miejsce w świecie zewnętrznym ${ }^{8}$.

Trudno w tym momencie nie przypomnieć sobie o Dopiskach na marginesie „Imienia róży”, w których Eco przekonywał, że książki mówią zawsze o innych książkach, wykorzystując je i odnosząc się do nich, a w czasie ich pisania trwa dialog pomiędzy tworzonym tekstem a wszystkimi innymi, które zostały już napisane'. Powieść Tajemniczy płomień królowej Loany jest praktyczną realizacją tej teorii, stanowi bowiem zbiór cytatów i aluzji do innych tekstów literatury i kultury, twór intertekstualny ${ }^{10}$ do granic możliwości.

7 Autor powieści opisuje ją słowami: „Dziewczyna z Polski, specjalizowała się w Warszawie w bibliotekoznawstwie, a kiedy reżim zaczął tam trzeszczeć, jeszcze przed zburzeniem muru berlińskiego udało się jej uzyskać pozwolenie na podróż naukową do Rzymu". U. Eco, dz. cyt., s. 52.

8 T. Maruszewski, dz. cyt., s. 117.

9 U. Eco, Dopiski na marginesie „Imienia róży”, w: tenże, Imię róży, przeł. A. Szymanowski, wyd. 6, Noir sur Blanc, Warszawa 2016, s. 721. Eco nawiązuje tu do tekstu Rolanda Barthesa Śmierć autora. Barthes, nauczyciel i przyjaciel Eco, w 1977 roku określił tekst „tkanką cytatów, pochodzących z nieskończenie wielu zakątków kultury”, autorów nazwał zaś wiecznymi kopistami, wzniosłymi i komicznymi, naśladującymi „gest uprzedni, pozbawiony początku”, których „władza polega wyłącznie na mieszaniu charakterów pisma, nastawianiu ich przeciwko sobie, tak by nigdy nie można się było oprzeć na którymś z nich z osobna”. W tym kontekście „życie może jedynie naśladować książkę, książka zaś jest jedynie tkaniną znaków, naśladowaniem zagubionego, odwleczonego w nieskończoność wzorca”, R. Barthes, Śmierć autora, „Teksty Drugie” 1999, nr 1-2, s. 250-251.

10 Relacje intertekstualne pomiędzy tekstami zachodzą w sytuacji, gdy dla interpretacji utworu znaczenie ma nie tylko geneza elementów zaczerpniętych z innego tekstu, lecz także ich rola w tekście. Jak zauważył Michał Głowiński, w obręb intertekstualności „wchodzą wyłącznie te relacje z innymi utworami, które stały się elementem strukturalnym, lub - jeśli kto woli - znaczeniowym (czy semantycznym), relacje zamierzone i w taki czy inny sposób widoczne, można by powiedzieć: przeznaczone dla czytelnika”, zob. M. Głowiński, O intertekstualności, „Pamiętnik Literacki" 1986, t. 77, nr 4, s. 77.

Renate Lachmann zaś definiuje intertekstualność jako „pamięć literatury”, określając przestrzeń między tekstami przestrzenią pamięci: „Przestrzeń między tekstami i przestrzeń wewnątrztekstowa, powstająca z doświadczenia przestrzeni międzytekstowej, stwarza owo napięcie między pozatekstualno-intertekstualnymi a intratekstualnymi aspektami, które czytelnik musi wytrzymać. Przestrzeń pamięci jest w taki sam sposób wpisana w tekst, jak ów wpisuje się w przestrzeń pamięci", zob. R. Lachmann, Mnemotechnika i symulakrum, w: Pamięć zbiorowa i kulturowa, 
Warto w tym miejscu wspomnieć o projekcie „Queen Loana Annotation Project” stworzonym w 2005 roku przez Erika Ketzana, zbierającym cytaty i odwołania do kultury, które rozpoznali czytelnicy powieści Eco ${ }^{11}$. Cytaty zostały umieszczone w serwisie internetowym typu Wiki, co oznacza, że jego treść można tworzyć i zmieniać za pomocą przeglądarki internetowej. Wraz z pojawieniem się nowych interpretacji książki czytelnicy mogą aktualizować stronę, dodając swoje pomysły i wnioski z lektury ${ }^{12}$. Fakt, że powstała taka strona, podkreśla tylko intertekstualny charakter omawianej powieści i jednocześnie omówione w poprzednim akapicie słowa Eco; jest to przykład dialogu, o którym pisał autor Imienia róży, pomiędzy konkretnym tekstem a wszystkimi innymi, które zna pisarz.

Od początku oczywiste jest, że główny bohater nieprzypadkowo nosi imię słynnego drukarza i wydawcy żyjącego we Włoszech na przełomie XVIII i XIX wie$\mathrm{ku}^{13}$. Literacki Bodoni, jak prawdziwy bibliofil, poświęca całe swoje życie książkom. Miłość do nich wydaje się przeznaczona mu od urodzenia nie tylko za sprawą imienia, jakie nosi, lecz także dzięki dziadkowi, który sprzedawał stare książki, i dzięki któremu mały Jambo wkraczał w fascynujący i tajemniczy świat oferowany przez pożółkłe woluminy. Kwestią czasu było więc, by bohater sam uzależnił swoje życie od książek. „Mówiłeś, że z imieniem, które ci dano, nie możesz postąpić inaczej”14, wyjaśnia mu jego żona.

red. M. Saryusz-Wolska, Kraków 2009, s. 307-308. Zdaniem Lachmann intertekstualność literatury jest więc ciągłym „pisaniem się na nowo” i przeformułowywaniem kultury, jest „działaniem pamięci i reinterpretacją kultury (książek) w jednym", tamże, s. 308.

11 Zob. The Mysterious Flame of Queen Loana, http://eco.ids-mannheim.de/wiki/The_Mysterious_Flame_of_Queen_Loana [dostęp 20.05.2017].

12 Uwagi czytelników są różne - od osób szukających w książce nawiązań do życia jej autora, np. „Solara - letni dom Umberta Eco, znajduje się w pobliżu Rimini. Nazwa Solara sugeruje słoneczne, szczęśliwe dzieciństwo", przez odbiorców odnoszących się do poprzednich książek pisarza, np. „pojęcie ustalonego punktu było głównym tematem Wahadła Foucaulta, w którym zostało użyte przede wszystkim do opisania jedynego ustalonego punktu we wszechświecie [...]. W tym cytacie z Tajemniczego płomienia królowej Loany Eco zdaje się opisywać powstający punkt drukowanego tekstu", aż po te głosy, które wyjaśniają trudniejsze zwroty w powieści, np. „fumifugium - późnołacińskie słowo oznaczające dym”. Obok tego występuje wiele wyjaśnień odwołujących się do historii, kultury i polityki Włoch oraz rozpoznania literackich i filmowych aluzji.

13 Giambattista Bodoni (1740-1813) - drukarz, zecer, wydawca. Od 1768 roku prowadził Książęcą Drukarnię w Parmie, a od 1770 także założoną przy niej odlewnię czcionek. W 1791 roku założył własną drukarnię. Opracował krój antykwy klasycystycznej, zwany bodoni, i ok. trzystu krojów pism czcionek. Zob. B. Bieńkowska, Książka na przestrzeni dziejów, Centrum Edukacji Bibliotekarskiej, Informacyjnej i Dokumentacyjnej im. Heleny Radlińskiej, Warszawa 2005, s. 319-320.

14 U. Eco, Tajemniczy płomień królowej..., s. 45. 
To, że przywiązanie do książek nie zniknęło wraz z utraconą przez Jamba pamięcią, pokazuje sytuacja, kiedy ogląda on swój dom po raz pierwszy od wypadku i wrażenie robi na nim korytarz wypełniony do sufitu regałami z książkami:

Poprowadziła mnie długim korytarzem o ścianach zabudowanych półkami pełnymi książek. Patrzyłem na grzbiety i większość rozpoznawałem. To znaczy rozpoznawałem tytuły: Narzeczeni, Orland szalony, Buszujący w zbożu... Po raz pierwszy odniosłem wrażenie, że znajduję się w miejscu, gdzie jest mi dobrze. Wyciągnąłem jeden tom i - nie patrząc jeszcze na okładkę - wziąłem go w prawą rękę za grzbiet, a kciukiem lewej przebiegłem po kartkach, z lekka je odchylając. Podobał mi się dźwięk, jaki wydawały ${ }^{15}$.

Takie sensoryczne spojrzenie na książkę, nie tylko jak na zawartość treściową, lecz także na formę materialną, jest charakterystyczne dla miłośników książek, doceniających fizyczne aspekty lektury - pożółkły papier, charakterystyczny zapach czy właśnie dźwięk, jaki wydają przewracane stronice. Dla tej kategorii czytelników ważny jest bezpośredni, zmysłowy kontakt z książką, nie tylko z tekstem, lecz także z całą oprawą, jaka mu towarzyszy.

Utrata pamięci z każdą chwilą coraz bardziej ogranicza autonomię bohatera, który wie o sobie tylko tyle, ile powiedzą mu inni ludzie, i skazuje go na życie bez poczucia własnej tożsamości. Bohater, który utracił świadomość swojej przeszłości, pragnie ją zrekonstruować za pomocą przywołania zapomnianych przedmiotów z dzieciństwa, przede wszystkim dawnych lektur, książek, czasopism i komiksów, które odnajduje na strychu rodzinnego domu. Próbując odpocząć i zregenerować siły, za namową żony wraca on do Piemontu, miejsca swojego dorastania. Szybko nabiera nadziei, że jego atmosfera i ukryte w nim skarby pozwolą mu przypomnieć sobie przeszłość. Ma nadzieję, że dom w Solarze stanie się areną spektakularnego zwycięstwa materialnych przedmiotów nad utraconą podmiotowością. Z chwilą przekroczenia progu domu niegdysiejsze śmieci stają się więc cennymi reliktami, a zapomniani bohaterowie przekształcają się w idoli nostalgicznych wspomnień. Wydaje się, że skazane na niepamięć przedmioty czekają, by wskazać bohaterowi drogę do przeszłości. Takie przekonanie koresponduje z poglądem, że pewne przedmioty „mają nam coś do powiedzenia”, pełniąc rolę miejsc pamięci. Wśród znalezisk są nie tylko książki, czasopisma i komiksy. To także szkolne zeszyty, podręczniki, klasery i kalendarzyki. Bohater sądzi, że w tych niepozornych przedmiotach zapisane jest jego życie, jest więc skazany na ich łaskę - co pozwolą mu sobie przypomnieć? Jakie ślady przeszłych wydarzeń przed nim odsłonią?

15 Tamże, s. 36. 


\section{Literatura i tekst zapisany jako medium pamięci}

Problematyka literatury będącej medium pamięci jest stosunkowo nowa ${ }^{16} \mathrm{i}$ wiąże się z ikonicznym zwrotem $\mathrm{w}$ badaniach literackich, a w konsekwencji - z popularnością poglądów o medialnym charakterze literatury. Składają się na nią zagadnienia, czy i w jaki sposób intertekstualność oraz kanoniczność literatury mogą zwiększyć efektywność jej oddziaływania w obrębie kultury pamięci ${ }^{17}$. Pamięć jest w tym kontekście postrzegana jako kategoria egzystencjalna nie tylko wpływająca na tożsamość indywidualną i tzw. bycie w świecie, lecz także będąca nośnikiem tożsamości zbiorowej ${ }^{18}$.

W dyskursie na temat wpływu pamięci na tożsamość indywidualną ważna jest kategoria pamięci kulturowej. Jest ona, obok pamięci komunikatywnej, jedną z form pamięci zbiorowej, czyli tego rodzaju pamięci, który kształtuje pamięć swoich członków. Pamięć indywidualna jest nierozerwalnie związana z pamięcią zbiorową, ponieważ nawet bardzo osobiste wspomnienia powstają dzięki komunikacji i interakcji w grupach społecznych ${ }^{19}$. Zgodnie z koncepcją Jana Assmanna na pamięć kulturową składa się charakterystyczny dla danej społeczności zbiór tekstów, wyobrażeń i rytuałów, w których mieści ona wyobrażenie o sobie samej ${ }^{20}$. Ten rodzaj pamięci wymaga utrwalenia na nośnikach materialnych lub rytualnych (w zbiorze gestów, słów i przedmiotów liturgicznych, przenoszących wydarzenia historyczne poza czas). Popularnymi nośnikami wykorzystywanymi w tym celu są pismo i słowo ${ }^{21}$, co czyni tę koncepcję uznaną wśród filologów i literaturoznawców ${ }^{22}$. Materiałem do badań nad pamięcią kulturową są więc głównie wytwory literackie, od klasyki literatury po teksty współczesne. Kultura pamięci jest zja-

16 Pamięć nie jest kategorią stricte literaturoznawczą, co sprawia, że czerpie ona z teorii i praktyki takich dyscyplin, jak psychologia, socjologia czy historia. Problematyka pamięci zaczęła być wyraźnie widoczna w dyskursie literaturoznawczym w latach 70. XX wieku, m.in. za sprawą literatury świadectwa - powstającej na fali dekolonizacji grup mniejszościowych i etnicznych - czy uznania dla psychoanalizy i Freudowskiego „powrotu do tego, co wyparte”. E. Rybicka, Miejsce, pamięć, literatura (w perspektywie geopoetyki), „Teksty Drugie” 2008, nr 1-2, s. 21-22.

17 Tamże, s. 23.

18 Tamże.

19 J. Assmann, Pamięć kulturowa. Pismo, zapamiętywanie i polityczna tożsamość w cywilizacjach starożytnych, przeł. A. Kryczyńska-Pham, Wydawnictwa Uniwersytetu Warszawskiego, Warszawa 2008, s. 51-52.

20 J. Assmann, Pamięć zbiorowa i tożsamość kulturowa, przeł. S. Dyroff, R. Żytyniec, „Borussia” 2003, $\mathrm{nr} 29$, s. 16.

21 Historia pamięci ewoluuje wraz z mediami - po piśmie kolejnymi przełomami były wynalazki druku oraz fotografii i mediów cyfrowych.

22 M. Saryusz-Wolska, Pamięć kulturowa, w: Modi memorandi. Leksykon kultury pamięci, red. M. Saryusz-Wolska, R. Traba, Wydawnictwo Naukowe Scholar, Warszawa 2014, s. 337-338. 
wiskiem uniwersalnym, jej celem jest „dochowanie społecznego zobowiązania” ${ }^{23}$, wybranie spośród elementów kultury tych, których nie wolno zapomnieć. Ważną rolę $\mathrm{w}$ tym procesie odgrywa pismo. Jiří Trávníček zauważa także, że to właśnie lektury integrują nas ze społeczeństwem, a dzięki czytaniu stajemy się jego pełnoprawnymi członkami ${ }^{24}$.

Wraz z chwilą rozpoczęcia przez Jamba zwiedzania domu w Solarze rozpoczyna się prawdziwy festiwal wspomnień. Bohater przemierza znajome korytarze i zagląda do pomieszczeń, które zamieszkiwał ze swoją rodziną. Ponownie bierze do rąk bliskie niegdyś przedmioty - swoją pierwszą encyklopedię, modlitewnik matki, atlasy, francuskie czasopisma kolekcjonowane przez jego dziadka. Pamięć o przeszłości noszą nie tylko czytane przez członków rodziny książki, lecz także komiksy, plakaty, a nawet puszki po herbacie i opakowania po papierosach. Znalezione przedmioty pokazują mu atmosferę, w jakiej dorastał - spokojną, nacechowaną "miłą staroświeckością"25, prowadzącą „w świat dnia poprzedniego"26. Dzięki obecności tych przedmiotów, a także atmosferze, jaką przywołują, ma nadzieję, że odzyska pamięć.

Znalezione dokumenty i przedmioty mogą być uznane za jedno z miejsc pamięci i słusznie zostały tak potraktowane przez bohatera. Pojęcie miejsc pamięci (lieux de mémoire) sformułował francuski historyk Pierre Nora ${ }^{27}$, zastanawiając się nad tym, w jaki sposób przeszłość jest obecna w teraźniejszości. W swoich rozważaniach doszedł on do wniosku, że miejsca pamięci ${ }^{28}$ to zinstytucjonalizowane formy zbiorowych wspomnień przeszłości ${ }^{29}$, czyli miejsca, w których pewne wspólnoty przechowują swoje pamiątki. Są wśród nich miejsca topograficzne (archiwa, biblioteki), miejsca monumenty (pomniki, cmentarze), miejsca symboliczne (rocznice, pielgrzymki) oraz miejsca funkcjonalne (autobiografie, podręczniki) ${ }^{30}$. W tym kontekście także literatura staje się miejscem pamięci, traktowanym jako „zobowiązanie przypominania tego, co zapomniane i wyparte”31.

Niecierpliwy Jambo czyta znalezione książki i czasopisma w sposób „chaotyczny i szalony” - jedne rzeczy przegląda pobieżnie, w inne wczytuje się dokładnie;

23 J. Assmann, Pamięć zbiorowa i tożsamość..., s. 46.

24 J. Trávníček, Życiorysy czytelnicze (zarys koncepcji), „Roczniki Biblioteczne”, R. 61, 2017, s. 230.

25 U. Eco, Tajemniczy płomień królowej..., s. 148.

26 Tamże.

27 Teksty Nory nie zostały przetłumaczone na język polski; poglądy historyka omawia m.in. Andrzej Szpociński. Zob. A. Szpociński, Miejsca pamięci (lieux de mémoire), „Teksty Drugie” 2008, nr 1-2, s. 11-20.

28 Szpociński zauważa, że trafniejszym tłumaczeniem lieux de mémoire byłoby „miejsca wspominania” czy też "miejsca, w których się wspomina”.

29 A. Szpociński, dz. cyt., s. 12.

30 Za: E. Rybicka, dz. cyt., s. 25.

31 Tamże, s. 32. 
stara się skupić na emocjach, które temu towarzyszą, wierząc że tych samych uczuć doświadczał, czytając te książki po raz pierwszy:

Zbyteczne wspominać cały zestaw tajemniczych płomieni, lekkich częstoskurczy, nagłych rumieńców, które wiele $\mathrm{z}$ tych lektur wywoływało we mnie na krótkie chwile. Potem znikały tak, jak się pojawiły, ustępując miejsca nowym przypływom gorąca $^{32}$.

Bodoni porównuje się do bohatera powieści Marcela Prousta, W poszukiwaniu straconego czasu (fr. À la recherche du temps perdu, 1911). U Marcela, bohatera książki, wspomnienia wywoływały magdalenki. Jambo liczy na to, że jego magdalenkami okażą się znalezione dokumenty; że przeglądając stronice dawniej czytanych woluminów, zacznie snuć opowieść o swojej przeszłości. Są to jednak złudne nadzieje, bohaterowi bowiem nie udaje się osiągnąć podobnego efektu. Elżbieta Winiecka zauważa, że Jambo jest wręcz przeciwieństwem bohatera powieści Prousta. Marcel opowiada swoją historię w oparciu o pamięć autobiograficzną, czyli tę, którą postać stworzona przez Eco utraciła. Marcel dysponuje własną biografią, Jambo natomiast - słowami, które odsyłają go do innych słów ${ }^{33}$. Sam Eco przyznał: „Kiedy to napisałem, uświadomiłem sobie, że zrobiłem dokładnie odwrotnie niż Proust: nie zajrzałem w głąb siebie, by znaleźć moją pamięć osobistą, lecz odszukałem ją z pamięci należącej do wszystkich, do całego mojego pokolenia" ${ }^{34}$. Słowa te doskonale korespondują ze wspomnianą już wcześniej tezą Assmanna o zbiorowym rodowodzie pamięci indywidualnej.

Paweł Wolski zauważa, że pozornie teza powieści Eco zakłada, iż człowiek jest sumą lektur, a teksty (które są zawsze wtórne) tworzą jego tożsamośćc ${ }^{35}$. Początkowo obrazy nie wywołują u Jamba konkretnych wspomnień, tylko uczucia - te najsilniejsze nazywa tajemniczym płomieniem. Na tym etapie bohater kojarzy, do kogo mogły należeć konkretne przedmioty (np. modlitewnik matki), lecz nie pamięta sytuacji, w których je widział. W ciągu dalszego przeglądania pamiątek pojawiają się pierwsze przebłyski pamięci. Trzymane w rękach przedmioty zaczynają nabierać znaczenia, bohater ma wrażenie, że znajdują swojego właściciela i właściwe miejsce w przeszłości. Oglądając pudełko po papierosach Macedonia, Jambo słyszy głos matki narzekającej na pożółkłe palce, które ma od nich jego ojciec; przeglądając książki Verne’a i Dumasa jest przekonany, że czytał je na balkonie.

32 U. Eco, Tajemniczy płomień królowej..., s. 124.

33 E. Winiecka, Poszerzanie pola literatury w „Tajemniczym płomieniu królowej Loany” Umberta Eco, „Zagadnienia Rodzajów Literackich” 2018, nr 58, s. 107.

34 Behind The Doors Of Umberto Eco, reż. Teri Wehn Damisch, Francja 2012 (tłum. własne).

35 P. Wolski, A jednak Księga. Tradycja i (po)nowoczesność w powieści „Tajemniczy płomień królowej Loany” Umberta Eco, „Pogranicza” 2006, nr 5, s. 39. 
Wciąż jednak nie znajduje niczego, co naprawdę obudzi jego pamięć o sobie, oglądane przedmioty są tylko pretekstem do snucia domysłów:

Kalendarzyki fryzjerskie mogły wzbudzać w dziecku niezdrowe zachcianki, może nie wolno mi było ich oglądać. Może na strychu dowiem się czegoś o kształtowaniu się mojej świadomości seksualnej [...]. Zobaczyłem wiele rzeczy, ale żadnego przedmiotu, który byłby naprawdę i tylko mój ${ }^{36}$.

W zakurzonej kolekcji znajdują się także propagandowe powieści dla młodzieży, które sprawiają, że Jambo zastanawia się, w jakim stopniu utożsamiał się z włoskim systemem totalitarnym. Andrzej Krzemiński zauważa, że:

Odtworzenie śmiertelnej zarazy pedagogiki ma dla Eco znaczenie dziś. Od tego, kim byłem, zależy odpowiedź na pytanie: kim jestem? Jeśli byłem małym faszystą odurzonym całym tym patriotycznym kanonem od Serca d'Amicisa po faszystowskie opowiadania z wojny abisyńskiej, to czy byłem wierzącym, czy jedynie oportunistą ${ }^{37}$

Szybko okazuje się, że przyjęta przez bohatera strategia odzyskiwania pamięci w toku zapoznawania się ze starymi dokumentami zaczarowuje go. Sytuację, w której znalazł się Jambo, Joanna Ugniewska tłumaczy tezami zaczerpniętymi od francuskiego socjologa Maurice’a Halbwachsa, wyjaśniając rozczarowanie, jakie spotyka osoby, które przeglądając pamiątki dzieciństwa, daremnie liczą na reminiscencje:

Wydaje się nam, że odnaleźliśmy stan umysłu, w którym byliśmy wówczas, żywość i precyzję dawnego wrażenia, nastrój i entuzjazm, które nam wówczas towarzyszyły. Na przeszkodzie stoi jednak doświadczenie człowieka dorosłego, które jest nieusuwalne, nawarstwione, filtrujące przeszłość ${ }^{38}$.

Zdaje sobie z tego sprawę także bohater powieści, który przyznaje w końcu:

To, co mi pozostało, nie jest już tym, co widziałem i słyszałem przez ostatnie dni, ani tym, co mogłem widzieć lub słyszeć jako dziecko. Jest wyobrażeniem, hipotezą opracowaną w wieku sześćdziesięciu lat w odniesieniu do tego, co mogłem myśleć w wieku dziesięciu lat. Zbyt mało, aby powiedzieć: wiem, że tak właśnie było ${ }^{39}$.

36 U. Eco, Tajemniczy płomień królowej..., s. 133.

37 A. Krzemiński, Człowiek z cytatów, „Polityka” 2004, nr 47, s. 76.

38 J. Ugniewska, Miejsca utracone. Szkice o pamięci i zapomnieniu we współczesnej literaturze włoskiej, Fundacja Zeszytów Literackich, Warszawa 2014, s. 111.

39 U. Eco, Tajemniczy płomień królowej..., s. 184. 
Jambo, początkowo pełny nadziei na odzyskanie pamięci i niejako „zidentyfikowanie się" z sobą z czasów młodości, z każdą kolejną pamiątką uświadamia sobie daremność podejmowanych prób. Pierwsze wspomnienia traktuje bezkrytycznie, zupełnie poddając się rekonstruowanym obrazom i atmosferze, jaką wytwarzają znalezione przedmioty, z czasem dochodzi jednak do wniosku, że nie mają one możliwości dokładnego odzwierciedlenia przeszłości. Wybrane wspomnienia, odtwarzane i rekonstruowane wielokrotnie, tracą swój pierwotny „wygląd”, w różnych okresach życia ulegają deformacjom ${ }^{40}$. Ulubione książki i namiętnie czytane przez bohatera komiksy (tytułowa Loana jest bohaterką jednego z nich) są zaś, jak określa to Ugniewska, wiedzą bezosobową i wspólną całemu pokoleniu ${ }^{41}, \mathrm{w}$ tym przypadku wspólną osobom dorastającym w okresie faszystowskich Włoch, nie mają zatem mocy przywołania dawnej aury i emocji z dzieciństwa. Są determinowane przez późniejsze doświadczenia.

Zamiar odtworzenia własnej tożsamości na podstawie niezliczonych materialnych śladów nie może się powieść, bohater ma ponownie do czynienia jedynie ze słowami, martwym językiem pozbawionym zmysłowej aury, wyobrażeniem, hipotezą tego, co odczuwal jako nastolatek ${ }^{42}$.

Bezowocne poszukiwania i ciągle wymykająca się pamięć doprowadzają Jamba na skraj wyczerpania, w którym momentem kulminacyjnym jest znalezienie „tej” książki, czyli unikatowego wydania dzieł Szekspira z $1623 \mathrm{roku}^{43}$. Paweł Wolski zauważa, że w tym momencie Jambo przemienia się z Czytelnika Modelowego ${ }^{44}$, próbującego bezskutecznie odtworzyć dawne przeżycia, w czytelnika empirycznego, którego pobudza cenne znalezisko. Kiedy silne emocje powodują wylew, pozostający w śpiączce bohater dopiero wtedy otrzymuje to, po co przyjechał do domu w Solarze. Od tej chwili Jambo, nieograniczony intelektem i wolą, poddaje się swobodnemu napływowi niekontrolowanych i przychodzących niechronologicznie obrazów, które zmierzają do najważniejszego momentu: ponownego ujrzenia twarzy ukochanej z dzieciństwa, Lili Saby, którą utożsamiał z królową Loaną. Krzemiński podsumowuje to słowami:

40 Warto w tym miejscu wspomnieć, że pamięć człowieka w psychologii bywa wiązana z metaforą śladu stopy na piasku. Zgodnie z tą teorią pamięć rozumiana jest jako materiał, na którym różne wydarzenia i fakty zostawiają ślady. Wraz z upływem czasu ślady te stają się jednak coraz bardziej rozmyte i trudniejsze do rozczytania. Zob. T. Maruszewski, dz. cyt., s. 12.

41 J. Ugniewska, dz. cyt., s. 113.

42 Tamże, s. 114.

43 O poszukiwaniu książki „jedynej” pisze także Małgorzata Góralska, zob. M. Góralska, W poszukiwaniu księgi jedynej... Bibliologiczne refleksje nad fenomenem książi, „Roczniki Biblioteczne” 2005, $\mathrm{nr} 49$, s. 503-514.

44 Według Eco każdy autor, tworząc swój tekst, kształtuje model hipotetycznego czytelnika, który „współpracuje” z nim podczas interpretacji tekstu. Jest to tzw. Czytelnik Modelowy, do którego zadań należy czytanie tekstu w określony, modelowy sposób. Zob. U. Eco, Czytelnik modelowy, przeł. P. Salwa, „Pamiętnik Literacki” 1987, nr 78, s. 287-305. 
Podobno w momencie śmierci umierający w mgnieniu oka przegląda film całego swego życia. Dla Yambo życie to tylko cytaty i obrazy. Finał powieści i prywatna apokalipsa antykwariusza to kiczowate varieté. Po schodach jego szkoły schodzą bohaterowie filmów, powieści i komiksów. Na koniec Ona, Lila-Loana, ubrana w przewiewny strój perskiej księżniczki, a obok niej dwaj muskularni Murzyni ${ }^{45}$.

Wszystko to, co Jambo przeglądał wcześniej, było częścią kultury masoweje, w której, zgodnie z definicją Georgesa Freidmanna ${ }^{47}$, zawiera się również klasyka literatury powielana w wysokich nakładach. Kultura masowa, podobnie jak niegdysiejszy wynalazek druku, dała możliwość nowego sposobu reprodukcji i dystrybucji treści kulturowych, zarówno tworzonych przez wielkich pisarzy, jak i twórców, których dziełom odmawia się wyższej wartości literackiej. Współczesna podmiotowość wykształciła się dzięki doświadczeniu literackiemu dostępnemu za sprawą kultury masowej. Bohater książki Eco, który - zanurzony w Łotmanowskiej semiosferze ${ }^{48}$ - sięga zarówno po Verne’a, jak i komiks czy ulotki propagandowe, by zrekonstruować własną tożsamość, tylko potwierdza tę tezę. Teksty, wybrane niejako z „oferty” kultury masowej, tworzą pewien kanon, zbiór dzieł, postaci, zdarzeń oraz artefaktów, które zostały uznane przez jakąś grupę - w przypadku omawianej powieści przez włoską młodzież czasów faszystowskich - za fundamentalne dla jej historii i tożsamości ${ }^{49}$. Lektury, znalezione przez bohatera w domu swojego dzieciństwa, tworzą kanon literacki, uważany za skuteczny instrument polityki kulturalnej, służący do narzucania pewnej wizji kultury i odrzucania innej czy też przyjmowania

45 A. Krzemiński, dz. cyt. s. 77. Yambo to imię głównego bohatera we włoskim oryginale powieści.

46 W niniejszym artykule przyjęto formalne kryteria kultury masowej, wyznaczone m.in. przez Antoninę Kłoskowską w książce Kultura masowa, zgodnie z którymi kultura masowa to ogół treści przekazywanych przez środki masowego komunikowania, bez wartościowania ich treści, zob. A. Kłoskowska, Kultura masowa. Obrona i krytyka, wyd. 4, Wydawnictwo Naukowe PWN, Warszawa 2005, s. 287.

47 Zgodnie z definicją Georgesa Friedmanna kultura masowa rozumiana jest jako „ogół kulturalnych dóbr konsumpcyjnych oddanych do dyspozycji publiczności, w najszerszym rozumieniu tego słowa, za pomocą masowego komunikowania w ramach cywilizacji technicznej". Za: A. Pasek-Gawlikowska, „Kultura masowa” i co dalej...?, „Rozprawy Społeczne” 2013, nr 2, s. 57.

48 Według Jurija Łotmana na kulturę składa się świat stworzony przez człowieka, który jest jednocześnie środowiskiem jego życia i treścią jego przeżyć. Opisywana przez Łotmana semiosfera, przestrzeń analogiczna do biosfery, jest równoznaczna z kulturą, będąca zarazem warunkiem i rezultatem rozwoju kultury. Cechą semiosfery jest jej przestrzenność, która oznacza przedstawienie pewnego obrazu świata, zawierającego ludzkie „uniwersum mitologiczne, naukowe modelowanie i życiowy "zdrowy rozsądek«", zob. M. Śmigła, Jurija Łotmana semiotyczna teoria kultury, „Estetyka i Krytyka” 2009, nr 17-18, s. 308.

49 A. Szpociński, M.P. Markowski, Kanon, w: Modi memorandi..., s. 182. 
jakichś wartości i negowania innych ${ }^{50}$. Znane $\mathrm{z}$ historii sytuacje masowego niszczenia lub ostrego cenzurowania książek są dowodem podejmowania prób stworzenia jednoznacznego przekazu, ukształtowania „właściwej” pamięci zbiorowej. Sam bohater zauważa w pewnym momencie: „Solara nie zwróciła mi dotąd niczego, co byłoby naprawdę i wyłącznie moje. Odkryłem ponownie tylko to, co przeczytałem tak samo jak wielu innych. Do tego sprowadzała się cała moja archeologia"51. Całe swoje poszukiwania określa zaś „szaleństwem bibliotecznego maniaka”52, który szuka ucieczki od prawdziwego życia do świata fikcji.

Pamięć indywidualna nie funkcjonuje w całkowitym oderwaniu od kontekstów społecznych. Zgodnie z tezą Halbwachsa bez odniesienia społecznego pamięć indywidualna nie mogłaby zaistnieć ani trwać, a jednostka dorastająca w zupełnej samotności nie posiadałaby pamięci ${ }^{53}$. Jan Assmann określa to zjawisko słowami: „Pamięć rozwija się w człowieku wraz z procesem jego socjalizacji. Co prawda tylko jednostki «mają» pamięć, ale jest ona ukształtowana przez zbiorowość"54. Same zbiorowości nie mają pamięci, jednak wyraźnie wpływają na ukształtowanie jej wśród jej członków.

Na pamięć osobistą niezaprzeczalny wpływ mają nie same wspomnienia, lecz także odczucia z nimi związane. Teza ta znajduje swoje odbicie w fabule Tajemniczego płomienia...: znalezienie cennego wydania utworu Szekspira wywarło na bohaterze tak duże wrażenie, ponieważ był erudytą i bibliofilem, nie tylko doskonale zdającym sobie sprawę z wartości tej edycji, lecz także emocjonalnie związanym z wyjątkowymi i niepowtarzalnymi książkami ${ }^{55}$. Dzieło Szekspira wywarło na bohaterze tak duże wrażenie ze względu na jego unikatowość i znaczenie, jakie sam bohater mu nadał. Wyjątkowość i niepowtarzalność tej edycji sprawia, że to właśnie ona jest „tą” księgą. Podważa to w pewien sposób przekonanie, że tożsamość człowieka tworzą same teksty. Wolski uznał, że tworzy ją konkretna książka, na którą składają się zarówno tekst, jak i jej materialny charakter. Pamiętając o teorii Halbwachsa, warto jednak dołączyć do tego trzeci element - emocje, które wywołuje w odbiorcy konkretna książka, rozumiana jako połączenie tekstu i formy materialnej.

Czarna dziura, ostatnie, co widzi bohater Tajemniczego płomienia, jest według Wolskiego „rozpłynięciem się w sieci tekstów, scaleniem się z tekstowym

50 Tamże, s. 185.

51 U. Eco, Tajemniczy płomień królowej..., s. 275.

52 Tamże, s. 400.

53 J. Assmann, Pamięć kulturowa..., s. 51.

54 Tamże.

55 W jednym z wywiadów Umberto Eco przyznał, że posiadanie wydania dzieł Szekspira jest pragnieniem każdego bibliofila: „W Tajemniczym płomieniu królowej Loany [...] ukazuję marzenia każdego kolekcjonera: trafić na Biblię Gutenberga albo na Pierwsze Folio z 1623 roku". J.-C. Carriere, U. Eco, Nie myśl, że książki znikna, Wydawnictwo W.A.B., Warszawa 2010, s. 141-142. 
światem"56. Zdaniem Krzemińskiego natomiast zakończenie pokazuje śmierć bohatera będącą „rozpacz[ą] intelektualisty, który w społeczeństwie medialnym zajmuje rolę wyroczni, ale często sam nie ma pojęcia o sprawach, w których się wypowiada”. Ta presja ma swoje źródło w ogólnym upadku społeczeństwa, utracie ideologii i w braku rzeczywistych autorytetów.

Jesteśmy zamknięci w wieży Babel i rzeczywista rozmowa między ludźmi i całymi kulturami utyka w miejscu. A nie będąc w stanie się porozumieć sięgamy do tych stereotypów, klisz i uprzedzeń kolportowanych przez kulturę masową, które zabiły antykwariusza w najnowszej powieści Umberto Eco ${ }^{57}$.

Pamiątki, tak namiętnie zbierane przez Jamba i jego dziadka, są właśnie elementem kultury masowej, a nie, co znamienne, kultury erudytów ${ }^{58}$. Wnioski te, płynące z lektury, są odzwierciedleniem poglądów Eco na kulturę masową - w swojej powieści pisarz pokazuje, że jeśli chcemy odnaleźć siebie na tle epoki, w której żyjemy, musimy sięgnąć po to, co nas otacza, a otaczają nas wytwory kultury masowej. Do pełnego obrazu siebie niezbędny jest jednak element unikatowości - coś, z czym będziemy mogli zidentyfikować się niemal wyłącznie my, coś, co nie jest wspólnym dobrem większej grupy społecznej. Bohater powieści Eco musi oszaleć, by to zrozumieć i w końcu odnaleźć siebie.

\section{Autor i ilustrator w jednej osobie}

Ilustracje, czyli utwory rysunkowe, malarskie, graficzne bądź fotograficzne, towarzyszące tekstowi pisanemu lub drukowanemu ${ }^{59}$, rozumiane jako związane z treścią uzupełnienie, mogą pełnić różnorakie funkcje - zdobniczą, interpretacyjną, ekspresywną, dokumentalną lub autoteliczną ${ }^{60}$. W utworach fabularnych, czyli takich, do których zalicza się Tajemniczy płomień królowej Loany, dominuje funkcja ekspresywna, oddziałująca na sferę emocji.

Nie ulega wątpliwości, że elementy graficzne umieszczone w powieści Eco nie mają służyć wyłącznie kontemplacji estetycznej. Wydawać by się mogło, że uzupełniają tekst - dzięki nim czytelnik ma możliwość zobaczenia przedmiotów, które są częścią fabuły; przedmiotów na tyle ważnych, że pełnią rolę pełnoprawnych,

56 P. Wolski, dz. cyt., s. 41.

57 A. Krzemiński, dz. cyt., s. 77.

58 R. Capozzi, The Mysterious Flame of Queen Loana. A Postmodern Historiographic Illustrated Novel of a Generation, „Forum Italicum” 2006, nr 2, s. 463.

59 J. Wiercińska, Sztuka i książka, Państwowe Wydawnictwo Naukowe, Warszawa 1986, s. 37.

60 Ilustracja, w: Encyklopedia wiedzy o książce, red. A. Birkenmajer i in., Zakład Narodowy im. Ossolińskich, Wrocław 1971, s. 953-954. 
drugoplanowych bohaterów ${ }^{61}$. Czy jednak tylko do tego sprowadza się ich rola? Wraz z postępującą lekturą czytelnik może odnieść wrażenie, że jest ona o wiele znaczniejsza. Ilustracje stanowią tu nie tylko materiał wzbogacający tekst. To nie treść utworu determinuje ilustracje, lecz odwrotnie - to one tworzą fabułę. Wraz $\mathrm{z}$ rozwojem akcji czytelnik uświadamia sobie, że to tekst został zbudowany na kanwie obrazów (lub przedmiotów na nich umieszczonych), a nie odwrotnie. W przypadku powieści ilustrowanych zwykle mamy do czynienia z tekstami literackimi, do których stworzony został materiał ilustracyjny. Najczęściej tekst powstaje wcześniej, a następnie tworzona jest jego graficzna interpretacja. Zdarza się także, że ilustracje powstają niemal równocześnie z tekstem, najczęściej wtedy, gdy autor jest także ilustratorem. Rzadziej mamy do czynienia z sytuacją, gdy materiał ilustracyjny wyprzedza tekst powieści. Zdaniem Marii Gadomskiej, właśnie wtedy, kiedy tekst powstaje na podstawie już gotowego materiału ilustracyjnego, związki ilustracji z tekstem są najbliższe ${ }^{62}$. Przy takiej korelacji tekstu z obrazem ilustracja jest „nie tyle uzupełnieniem, ile elementem, który mógłby zastąpić wyrwany fragment, co świadczy o zgodności semiotycznej”’3. Ilustracje nie mają w takim przypadku charakteru symbolicznego, są one ,jasne, proste, zrozumiałe dla każdego" ${ }^{\circ 4}$.

Czytając powieść Umberta Eco, można wyobrazić sobie autora pochylonego nad stosem różności, dobierającego przypadkowo przedmioty, których wizerunki pojawią się na kartach książki. Zapoznając się pobieżnie z książką po raz pierwszy, można odnieść wrażenie, że przedmioty te nie mają ze sobą nic wspólnego, że - nawet jeśli są elementem fabuły - mogły w ich miejsce zostać wybrane inne elementy bez szkody dla treści utworu. Ten heterogeniczny zestaw zakurzonych i zapomnianych przedmiotów wraz z rozwijaniem się akcji staje się jednak mniej przypadkowy, niż wydawało się na początku lektury. Okazuje się, że są to przedmioty nie tylko mieszczące wspomnienia o przeszłości, lecz także o tożsamości bohatera. Każdy z nich jest dla niego w jakiś sposób cenny. Każdy umiejscowiony został w jakiejś historii i szczegółowo omówiony przez autora tak, by czytelnik mógł dobrze się z nim zapoznać. Najnowszy Melzi to nie tylko popis znajomości przez Eco leksykonu z początku XX wieku i doskonała wiedza o zawartości tej książki, lecz także emocje, jakie pojawiają się w młodym chłopcu, który po raz pierwszy poznaje trzydzieści różnych

61 Grzegorz Grochowski zauważa nawet, że ilustracje tak dalece angażują uwagę czytelnika, że „niemal awansują do pozycji głównego protagonisty omawianej powieści”, zob. G. Grochowski, Na styku kodów. O literackich użyciach znaków ikonicznych, „Teksty Drugie” 2006, nr 4, s. 64. Jako przykład wskazuje ona tendencje XIX- i XX-wiecznej literatury i poezji, np. książki dla dzieci pisane przez Marię Konopnicką i Artura Oppmana do zagranicznych ilustracji dostarczanych przez wydawcę (Michała Arcta). M. Gadomska, Zależności między treścią a forma graficzną w źródłach poezji z przełomu XIX i XX wieku, „Z badań nad polskimi księgozbiorami historycznymi" 1991, t. 11: Pogranicza, s. 131.

Tamże, s. 136.

64 Tamże. 
sposobów na poddanie człowieka torturom. To nie tylko suche hasła informujące o tym, kim byli Platon i Baudelaire, lecz refleksja dojrzałego bohatera na temat tego, w jaki sposób formowała się wiedza małego chłopca, poznającego świat z tej potężnej encyklopedii. Czy taki opis pojawiających się w powieści przedmiotów mógł być możliwy, gdyby pisarz sam nie był z nimi związany?

O tym, że Eco spędzał czas, przeglądając archiwalne numery czasopism, można dowiedzieć się między innymi z jednego $\mathrm{z}$ felietonów pisarza, opublikowanego w 2014 roku na łamach włoskiego „L'Espresso”. W felietonie-liście skierowanym do wnuka autor pisze: „przeglądałem stare pisma zgromadzone w składziku naszego domu, i dlatego zachęcam Cię, byś przeglądał nawet stare czasopisma, bo to też jest sposób na to, by poznać, co się działo, zanim się urodziłeś”'65. Pisarz nigdy nie trzymał w tajemnicy także pasji do zbierania przeróżnych szpargałów - od lat kolekcjonował komiksy, kalendarzyki, płyty, pudełka od zapałek, afisze, pocztówki i wiele innych drobiazgów.

Materiał ilustracyjny został skomponowany przez Eco. Znajdują się w nim elementy autobiograficzne - rysunek autorstwa pisarza, zdjęcie przedstawiające Eco i jego siostrę, fotografie z rodzinnego domu. Świadomość, że większość umieszczonych w książce materiałów pochodzi ze zbiorów autora, wpływa na odbiór zawartych $\mathrm{w}$ książce treści ${ }^{66}$. Nawet jeśli czytelnik nie zna faktów z życia pisarza, czuje, że główny bohater może wyrażać rozterki, wątpliwości i troski nieobce samemu Eco. Dzięki tej książce pisarz urodzony w 1932 roku, czyli rok po literackim Bodonim i dziesięć lat po objęciu władzy przez faszystów, odtwarza nie tylko obraz

65 U. Eco, O pożytkach oglądania się za dziewczynami, przeł. J. Mikołajewski, „Gazeta Wyborcza” 2016, http://wyborcza.pl/magazyn/1,124059,19961172,o-pozytkach-z-ogladania-sie-za-dziewczynami.html [dostęp 12.05.2017].

66 Mariusz Czubaj, w recenzji zamieszczonej na łamach „Polityki”, zauważa, nawet że Tajemniczy płomień królowej Loany jest powieścią, która „ostentacyjnie odwołuje się do biografii autora”, Brenda Hammack zaś nazywa tę powieść najbardziej autobiograficzną fikcją Eco, zob. M. Czubaj, Samotność prostych równoległych, „Polityka” 2005, nr 39, s. 68; B. Hammack, Mapping the Interstices. Reif Larsen's and Umberto Eco's Illustrated Texts, "Interfictions. A Journal of Interstitial Arts" 2013, iss. 2, http://interfictions.com/mapping-the-interstices-reif-larsens-andumberto-ecos-illustrated-texts-brenda-hammack/ [dostęp 14.01.2018].

Co ciekawe, sam pisarz, świadomy tych skojarzeń, określił autobiograficzność tej powieści na $30 \%$. Z jednego z wywiadów z pisarzem dowiadujemy się, że jednym z powodów napisania tej książki była chęć pokazania idei platonicznej miłości z czasów szkolnych, do czego sprowokowały go jego przeżycia i doświadczenia z młodości. Historia, którą poznajemy w wywiadzie, opowiada o szkolnej miłości Eco. W szkole przyszły pisarz nigdy nie zdecydował się wyznać swoich uczuć koleżance, a gdy w końcu zdecydował się na ten krok, okazało się, że kobieta nie żyje. Pomysł na książkę powstał więc częściowo z niemożności opowiedzenia dawnej ukochanej tej historii. Równie ważną rolę odegrała chęć zaprezentowania zgromadzonych pamiątek: „Chciałem opowiedzieć historię, która pozwoliłaby mi wykorzystać wszystkie moje komiksy, wszystkie piosenki i inne rzeczy z mojego dzieciństwa", zob. Behind The Doors... (tłum. własne). 
totalitarnych Włoch, lecz także swoje dzieciństwo i młodość na jego tle. Poprzez intertekstualne odniesienia, oparte na materiale ilustracyjnym, odkrywa specyfikę włoskiej kultury popularnej lat 30., 40. i 50. XX wieku.

Ilustracje w tej powieści, nazwane przez jednego z włoskich krytyków „tatuażami na skórze tekstu" ${ }^{37}$, pełnią rolę nie tyle wyobrażeń, ile przedstawień, dzięki czemu na pierwszy plan wysuwa się tu funkcja poznawcza. Dokumentują one obraz włoskiej kultury czasów faszystowskich. Takie autorskie dopełnienie świata przedstawionego, dokonane przez ilustracje, może być w tym kontekście postrzegane jako rodzaj zabezpieczenia przekazywanych informacji, przypieczętowania ich wyglądu. W pewien sposób „uwierzytelnia” opisywany przez autora świat, związując tekst z ilustracją. Elżbieta Rybicka trafnie zauważa, że pamięć i wyobraźnia potrzebują materialnego śladu przeszłości, a śladem tym są wizerunki przedmiotów umieszczone na ilustracjach.

Ten ścisły związek pomiędzy gestem pisarskim a materialnością miejsca dowodzi, iż miejsce i literatura potrzebują się wzajemnie: przestrzeń wydrążona z pamięci odzyskuje swą historię i przeszłość (nawet jeśli ma ona niekiedy status imaginacyjny), literatura z kolei zyskuje zakotwiczenie w geografii i historiii ${ }^{68}$.

Wspomniane przez Rybicką materialne miejsca są w powieści Eco niczym innym jak ilustracjami unaoczniającymi opisywane elementy fabuły - książki, komiksy, plakaty czy artykuły z prasy są śladami miejsc, w których „bywał” bohater i które autor Tajemniczego płomienia... pragnie upamiętnić.

W artykule Na styku kodów Grzegorz Grochowski zwrócił uwagę na to, że współczesna literatura mieści dzieła, których ilustracje wykraczają daleko poza tradycyjnie rozumiany materiał graficzny - mający za zadanie objaśnić tekst czy podnieść jego walory estetyczne - i stają się integralną częścią narracji ${ }^{69}$, najczęściej stworzoną bądź wybraną przez autora tekstu. Grochowski zauważył, że w sytuacji, kiedy ilustracje tworzone są przez samego autora książki, pojawia się pytanie, czy będąc - przejmując to określenie za Seweryną Wysłouch - „świadectwem autorskiej interpretacji" ${ }^{70}$, są one związane $\mathrm{z}$ tekstem w sposób nierozerwalny („nieusuwalny" $\left.{ }^{\prime 1}\right)$. Obrazy umieszczone w dziele poddawane są rekontekstualizacji, tworząc nowe sensy figuratywne, alegoryczne bądź metaforyczne ${ }^{72}$; ukierun-

67 Za: E. Sawicka, Tatuaż na skórze tekstu, „Rzeczpospolita” 2005, nr 254, s. A16.

68 E. Rybicka, dz. cyt., s. 26.

69 Tamże, s. 50.

70 S. Wysłouch, Ilustracja autorska - casus Brunona Schulza, „Teksty Drugie” 1992, nr 5, s. 120, za:

G. Grochowski, dz. cyt., s. 49.

71 G. Grochowski, dz. cyt., s. 49.

72 Tamże, s. 56. 
kowanie percepcji czytelnika następuje zaś za sprawą wypowiedzi językowej towarzyszącej ilustracji ${ }^{73}$. Wobec tego, jak zauważa Grochowski, ikony wykorzystywane w tekstach literackich winny być traktowane jako znaki nieautonomiczne:

To głównie materiał słowny wyzwala semantyczny potencjał obrazu, nadaje kierunek znaczeniorodnym procesom i pozostaje nadrzędnym poziomem komunikacji, decydując o całościowym charakterze i tożsamości przekazu ${ }^{74}$.

Słowo i obraz są w powieści nierozdzielnymi składnikami, które wspólnie tworzą powieść. Połączenie to sprawia, że kierowany do czytelnika przekaz wizualno-werbalny jest o wiele silniejszy niż w przypadku samego tekstu - czytając o zmaganiach bohatera z odnalezionymi przedmiotami, a później obserwując, kiedy pewne elementy jego przeszłości zaczynają mu się przypominać, ma się wrażenie uczestniczenia w sytuacji bardzo intymnej. Tego typu uczucia towarzyszą procesowi lektury często, lecz kiedy opisywane przedmioty możemy zobaczyć na własne oczy, a nie tylko je sobie wyobrażać, wrażenie to zostaje spotęgowane ${ }^{75}$.

Odsłanianie miejsc pamięci w literaturze nie sprowadza się wyłącznie do dokumentowania, utrwalania czy archiwizowania przeszłości. Rybicka zauważa, że ważny jest w tym przypadku również „dialog lub poróżnienie, niekiedy nawet wyraźny spór z historią i tradycją"76. Taki dialog może pojawić się w powieści Eco za sprawą skonfrontowania własnej opinii na temat zilustrowanych przedmiotów ze sposobem przedstawienia ich przez autora powieści, a także porównania własnych przeżyć estetycznych wynikających z oglądania tych ilustracji z przeżyciami, które przedmioty te wzbudziły u bohatera. Wyjątkowo ciekawy dialog musi pojawić się pomiędzy autorem powieści a jej czytelnikami z pokolenia, o którym opowiada fabuła książki. Osoby te mogą bowiem porównać własne wspomnienia i przeżycia wynikające $\mathrm{z}$ odbioru popularnych wówczas wytworów kultury masowej.

73 Tamże.

74 Tamże, s. 56.

75 Jak zauważa Grochowski, znaczenie ilustracji umieszczonych w powieści (na przykład portretu Napoleona narysowanego przez Jamba) koresponduje z teoretyczną tezą Eco, zawartą w Nieobecnej strukturze, przekonującą, że „jeśli znak ikoniczny ma właściwości z czymś wspólne, to nie z przedmiotem, ale z postrzegalnym modelem przedmiotu; jest konstruowany i rozpoznawalny za pomocą tych samych zabiegów myślowych, jakich dokonujemy dla skonstruowania danego pojęcia". Podobnie znaczki pocztowe przedstawiające egzotyczne kraje nie są tylko przedstawieniami tych konkretnych miejsc, lecz „zbiorem onirycznych obrazów”, ponieważ tak jawiły się one bohaterowi powieści. Wizerunki przedmiotów, które pomieścił Eco w swojej powieści, odsyłają więc nie tylko do dokumentów kultury, lecz także do fantazji i skojarzeń bohatera: „Odniesienia mnożą się, ale żadne z nich nie tworzy jakiejś stabilnej, motywowanej relacji, żadne nie zyskuje statusu obiektywnego modelu", zob. G. Grochowski, dz. cyt., s. 66 Tamże. 
Odnajdują je w swojej przeszłości i postrzegają w osobisty sposób, prowadząc do nowych, indywidualnych odczytań powieści.

Brenda Hammack konkluduje, że podczas lektury tekstów ilustrowanych czytelnik wyrusza w podróż, która jest bardziej wewnętrzna, filozoficzna i wyobrażeniowa. Jeri Kroll zachęca zaś myślicieli, pisarzy i nauczycieli do uznania takiego tekstu za formę przewodnika turystycznego, przygotowującego czytelnika do odkrywania nowych granic, zarówno wewnętrznych, jak i zewnętrznych ${ }^{77}$.

\section{Powieść metamedialna czy książka hipertekstowa?}

$\mathrm{Na}$ koniec warto wspomnieć jeszcze o genologicznych konotacjach powieści Tajemniczy płomień..., na które wpływa zarówno jej układ, jak i umieszczone w niej ilustracje. Sposób, w jaki tekst utworu koresponduje z materiałem ilustracyjnym, czyni - zdaniem Elżbiety Winieckiej - powieść tę czymś więcej niż tylko powieścią ilustrowaną. Badaczka nazywa ją powieścią metamedialną czy też medium polisemiotycznym, które swoją strukturą nawiązuje do multimedialnych hipertekstów ${ }^{78}$, co - zdaniem Winieckiej - poszerza pole samej literatury ${ }^{79}$. Również Rocco Capozzi podkreśla hipertekstowy charakter tej powieści, nazywając ją obrazowym i multimedialnym rodzajem opowiadania (storytelling ${ }^{80}$ oraz hipertekstową, historiograficzną powieścią ilustrowaną. Zauważa także, że ilustracje z jednej strony pełnią funkcję dokumentacyjną, a z drugiej mogą być źródłem kolejnych mikronarracji, czyli historii, które za ich pomocą może stworzyć sam czytelnik. Zestawienie słów i obrazów w powieści zdolne jest wygenerować tysiące nowych historii ${ }^{81}$.

Co ciekawe, Capozzi wnioskuje też, że znajdujące się w powieści obrazy nie mają na celu poznania bohatera ani zilustrowania jego słów czy osobowości, a w zaprezentowanym materiale ilustracyjnym znaleźć można jedynie kilka ilustracji, które bezpośrednio go dotyczą. Zdaniem badacza celem materiału graficznego jest zaangażowanie czytelnika (wedle jego kompetencji i możliwości) w dynamikę komponentów wzrokowych i słuchowych, które oferuje powieść. Oglądając materiał graficzny, ciągle przesuwamy się więc z dokumentu do fikcji, od tzw. światów możliwych do historii. Także Elżbieta Winiecka stwierdza, że obrazy te „nie są [...] wyłącznie ilustracją powielającą przekaz werbalny, lecz

77 B. Hammack, dz. cyt.

78 E. Winiecka, dz. cyt., s. 105.

79 Warto jednak pamiętać, że metamedialny charakter powieści ma znaczenie metaforyczne, ponieważ termin metamedium stworzony został do określenia komputera, który dzięki technologii cyfrowej symuluje wszystkie inne media. Tamże, s. 102

80 R. Capozzi, dz. cyt., s. 463.

81 Tamże. 
rodzajem zainscenizowanych hiperłącz, odsyłających do kolejnych źródeł"82. Interpretacja ta pokrywa się w pewnym stopniu ze słowami Eco, który wyraźnie zaznaczał, że od wieków ludzie czytają książki hipertekstowo, „skacząc” po cytatach i fragmentach tekstu ${ }^{83}$. Co ciekawe, hipertekstowość (czy też hipertekstualność) utworów literackich widział Eco w związkach elementów fabuły z wyobraźnią bądź pamięcią czytelnika. Zdaniem Eco dzieło literackie wymaga od czytelnika dostrzegania tego, że poszczególne wątki utworu do siebie nawiązują, a zrozumienie jednego wymusza najczęściej pamiętanie o tym, który pojawił się na poprzednich kartach książki ${ }^{84}$.

Warto dodać także, że powieść została określona przez Marie Spruyt mianem powieści graficznej (graphic novel). Spruyt przytacza definicję powieści graficznej Willa Eisnera, który postrzega ten typ powieści jako rozmieszczenie obrazów i słów w starannie wyważonej proporcji w ramach jakiegoś medium. Czytelnik postawiony jest więc wobec dwóch elementów - fikcji (składają na nią m.in. fabuła, bohaterowie, temat) oraz składni i gramatyki samej grafiki (perspektywa, czcionka, kolory itd.). Tak definiowana powieść graficzna uważana jest za dzieło będące połączeniem sztuki, historii i literatury ${ }^{85}$. Spruyt uważa, że powieść, która opisuje kulturę Włoch w czasach faszystowskich, a więc dorastania zarówno autora, jak i jego bohatera, jest skrzyżowaniem dwóch typów opowieści, literackiej i historycznej, a ta mieszanka sztuki i tekstu jako medium do opowiadania historii kwalifikuje ją jako powieść graficzną ${ }^{86}$.

Cechy hipertekstowości nadaje omawianej powieści także sposób prowadzenia narracji, zwłaszcza drugiej części, w której bohater zapada w śpiączkę i przypomina sobie wydarzenia z przeszłości. Fragmentaryczność i niechronologiczność napływających do Jamba wspomnień sprawiają, że nie musimy czytać tej części linearnie, a kolejność wspomnień, z jakimi będzie zapoznawał się czytelnik, nie ma znaczenia dla fabuły powieści.

Tajemniczy płomień królowej Loany nosi w sobie cechy charakterystyczne dla powieści hipertekstowej, przede wszystkim ze względu na narrację przeciwstawiającą się pasywnej lekturze tradycyjnej, drukowanej książki. Niechronologiczność, fragmentaryczność przedstawionych wydarzeń, gęsta intertekstualna sieć, a także wyjątkowe powiązania obrazu ze słowem sprawiają, że możemy nazwać ją książką noszącą ślady hipertekstowości. Nie można jednak uznać jej za książkę stricte

82 E. Winiecka, dz. cyt., s. 113.

83 U. Eco, Śmierć książki? Nie!, „Notes Wydawniczy” 2001, nr 9 (113), s. 29.

84 U. Eco, tamże, s. 29.

85 M. Spruyt, Umberto Eco's The Mysterious Flame of Queen Loana. A conduit for culture, consciousness and cognition, „Inkanyiso Journal” 2010, nr 2, s. 2.

86 Tamże. 
hipertekstową, która $\mathrm{z}$ definicji ${ }^{87}$ powinna być odczytywana na interaktywnym, elektronicznym ekranie i prowokować czytelnika do wykonywania określonych operacji. Literaturoznawczy punkt widzenia, określający tę powieść metamedialną, hipertekstową czy też bardzo często hipertekstualną, zasadza się na pewnym metaforycznym postrzeganiu hipertekstu. Metafory te doskonale odzwierciedlają jednak zmiany, jakie zachodzą obecnie w literaturze.

\section{Podsumowanie}

Eco został poproszony przez jednego z dziennikarzy o opisanie fabuły Tajemniczego płomienia królowej Loany w jednym zdaniu. Powiedział wówczas: „Sposób na odbudowanie własnej pamięci na obiektywnej pamięci pokolenia"88. Umberto Eco za pomocą tej książki postanowił przypomnieć, że kultura masowa zdominowała społeczeństwo i tworzy ludzką tożsamość, stając się ważnym składnikiem edukacji. Przewrotnie podkreśla jednak, że tylko to, co wyjątkowe i niepowtarzalne może mieć ponadczasową wartość i rzeczywisty wpływ na człowieka.

Inspiracją do powstania powieści były ilustracje, zostały więc włączone w strukturę dzieła. Książka ta jest jednak nie tylko pięknie zilustrowaną powieścią o historii kultury popularnej Włoch lat 30. i 40. Można ją także odczytywać jako historię konkretnego pokolenia, czyli generacji Jamba i samego Eco, a liczne ilustracje, pełniące przede wszystkim rolę poznawczą, a dopiero w dalszej kolejności dokumentacyjną, czynią ją jeszcze bardziej interesującą, sprawiając, że mamy w tym przypadku do czynienia ze świadectwem dominacji audiowizualnego aspektu współczesnej kultury.

\section{Bibliografia}

Assmann Jan, Pamięć kulturowa. Pismo, zapamiętywanie i polityczna tożsamość $w$ cywilizacjach starożytnych, przeł. Anna Kryczyńska-Pham, Wydawnictwa Uniwersytetu Warszawskiego, Warszawa 2008.

Assmann Jan, Pamięć zbiorowa i tożsamość kulturowa, przeł. Stefan Dyroff, Rafał Żytyniec, „Borussia” 2003, nr 29, s. 11-16.

Barthes Roland, Śmierć autora, „Teksty Drugie” 1991, nr 1-2, s. 247-251.

87 Autor terminu hipertekst, Ted Nelson, napisał w 1965 roku: „wprowadzam termin hipertekst, który będzie oznaczał materiał pisemny lub graficzny powiązany w tak skomplikowany sposób, że nie może być prezentowany lub reprezentowany na papierze”, za: Ł. Matuszyk, Po drugiej stronie ekranu. O pochodzeniu i charakterze e-liberatury, „Ogrody Nauk i Sztuk” 2015, nr 5, s. 583.

88

Behind The Doors... (tłum. własne). 
Behind The Doors Of Umberto Eco, reż. Teri Wehn-Damisch, Francja 2012.

Bieńkowska Barbara, Książka na przestrzeni dziejów, Centrum Edukacji Bibliotekarskiej, Informacyjnej i Dokumentacyjnej im. Heleny Radlińskiej, Warszawa 2005. Capozzi Rocco, The Mysterious Flame of Queen Loana. A Postmodern Historiographic Illustrated Novel of a Generation, „Forum Italicum” 2006, 40, nr 2, s. 462-486.

Carriere Jean-Claude, Eco Umberto, Nie myśl, że książki znikną, przeł. Jan Kortas, Wydawnictwo W.A.B., Warszawa 2010.

Czubaj Mariusz, Samotność prostych równolegtych, „Polityka” 2005, nr 39, s. 68-69.

Eco Umberto, Czytelnik modelowy, przeł. Piotr Salwa, „Pamiętnik Literacki” 1987, nr 78, s. 287-305.

Eco Umberto, Dopiski na marginesie „Imienia róży”, w: Umberto Eco, Imię róży, przeł. Adam Szymanowski, wyd. 6, Noir sur Blanc, Warszawa 2016.

Eco Umberto, O pożytkach oglądania sięza dziewczynami, przeł. Jarosław Mikołajewski, „Gazeta Wyborcza” 2016, http://wyborcza.pl/magazyn/1,124059,19961172,o-pozytkach-z-ogladania-sie-za-dziewczynami.html [dostęp 12.05.2017].

Eco Umberto, Tajemniczy płomień królowej Loany, przeł. Krzysztof Żaboklicki, Noir sur Blanc, Warszawa 2005.

Gadomska Maria, Zależności między treścia w forma graficzna w źródłach poezji z przełomu XIX i XX wieku, „Z badań nad polskimi księgozbiorami historycznymi" 1991, t. 11: Pogranicza, s. 129-156.

Głowiński Michał, O intertekstualności, „Pamiętnik Literacki” 1986, (77), nr 4, s. $75-100$.

Góralska Małgorzata, Piśmienność i rewolucja cyfrowa, Wydawnictwo Uniwersytetu Wrocławskiego, Wrocław 2012.

Góralska Małgorzata, W poszukiwaniu księgi jedynej... Bibliologiczne refleksje nad fenomenem ksiązki, „Roczniki Biblioteczne” 2005, R. 49, s. 503-514.

Grochowski Grzegorz, Na styku kodów. O literackich użyciach znaków ikonicznych, „Teksty Drugie” 2006, nr 4, s. 47-71.

Hammack Brenda, Mapping the Interstices. Reif Larsen's and Umberto Eco's Illustrated Texts, „Interfictions: A Journal of Interstitial Arts” 2013, iss. 2, http://interfictions.com/mapping-the-interstices-reif-larsens-and-umberto-ecos-illustratedtexts-brenda-hammack/ [dostęp 14.01.2018].

Ilustracja, w: Encyklopedia wiedzy o książce, red. Aleksander Birkenmajer i in., Zakład Narodowy im. Ossolińskich, Wrocław 1971, s. 952-953.

Kłoskowska Antonina, Kultura masowa. Obrona i krytyka, wyd. 4, Wydawnictwo Naukowe PWN, Warszawa 2005.

Krzemiński Adam, Człowiek z cytatów, „Polityka” 2004, nr 47, s. 76-77.

Lachmann Renate, Mnemotechnika i symulakrum, w: Pamięć zbiorowa i kulturowa, red. Magdalena Saryusz-Wolska, Universitas, Kraków 2009, s. 285-322.

Maruszewski Tomasz, Pamięć autobiograficzna, Gdańskie Wydawnictwo Psychologiczne, Gdańsk 2005. 
Matuszyk Łukasz, Po drugiej stronie ekranu. O pochodzeniu i charakterze e-liberatury, „Ogrody Nauk i Sztuk” 2015, nr 5, s. 577-585.

$\mathrm{Ng}$ David, Eco and the Funnymen. Interview with Eco, Village Voice 2005, https:// www.villagevoice.com/2005/06/28/eco-and-the-funnymen/ [dostęp 12.05.2017].

Pasek-Gawlikowska Agata, „Kultura masowa” i co dalej...?, „Rozprawy Społeczne” 2013, nr 2, s. 57-66.

Rybicka Elżbieta, Miejsce, pamięć, literatura (w perspektywie geopoetyki), „Teksty Drugie" 2008, nr 1-2, s. 19-32.

Saryusz-Wolska Magdalena, Pamięć kulturowa, w: Modi memorandi. Leksykon kultury pamięci, red. Magdalena Saryusz-Wolska, Robert Traba, Wydawnictwo Naukowe Scholar, Warszawa 2014, s. 337-338.

Sawicka Elżbieta, Tatuaż na skórze tekstu, „Rzeczpospolita” 2005, nr 254, s. A16.

Spruyt Marie, Umberto Eco's The Mysterious Flame of Queen Loana. A conduit for culture, consciousness and cognition, „Inkanyiso Journal” 2010, nr 2, s. 1-6.

Szpociński Andrzej, Miejsca pamięci (lieux de mémoire), „Teksty Drugie” 2008, nr 4, s. 11-20.

Szpociński Andrzej, Markowski Michał Paweł, Kanon, w: Modi memorandi. Leksykon kultury pamięci, red. M. Saryusz-Wolska, R. Traba, Wydawnictwo Naukowe Scholar, Warszawa 2014, s. 182-186.

Śmigła Magdalena, Jurija Łotmana semiotyczna teoria kultury, „Estetyka i Krytyka” 2009, nr 17-18, s. 265-270.

The Mysterious Flame of Queen Loana, http://eco.ids-mannheim.de/wiki/TheMysterious_Flame_of_Queen_Loana [dostęp 20.05.2017].

Trávníček Jiří, Życiorysy czytelnicze (zarys koncepcji), „Roczniki Biblioteczne” 2017, R. 61, s. 227-240.

Trybuś Krzysztof, Literatura, w: Modi memorandi. Leksykon kultury pamięci, red. M. Saryusz-Wolska, R. Traba, Wydawnictwo Naukowe Scholar, Warszawa 2014, s. 205-210.

Ugniewska Joanna, Miejsca utracone. Szkice o pamięci i zapomnieniu we współczesnej literaturze włoskiej, Fundacja Zeszytów Literackich, Warszawa 2014.

Wiercińska Janina, Sztuka i książka, Państwowe Wydawnictwo Naukowe, Warszawa 1986.

Winiecka Elżbieta, Poszerzanie pola literatury $w$ „Tajemniczym płomieniu królowej Loany” Umberta Eco, „Zagadnienia Rodzajów Literackich” 2015, t. 58, z. 2, s. 101-118.

Wolski Paweł, A jednak Księga. Tradycja i (po)nowoczesność w powieści „Tajemniczy płomień królowej Loany” Umberta Eco, „Pogranicza” 2006, nr 5, s. 38-44. 


\title{
Memory of reading and the reader's identity in The Mysterious Flame of Queen Loana by Umberto Eco
}

\author{
Summary
}

The subject of this article is bibliological reflection on Umberto Eco's novel. Its storyline is a pretext for asking the questions about the reader's identity. Is human the sum of all the texts one has read? What is the importance of books for constructing the self? How does the printed text influence its reception, given the location of literature in the context of mass culture? Moreover, the article reflects on the role of illustrations in literature as well as on the way in which illustrations function in a printed text. Furthermore, the article investigates the roles of pictures and their importance for the composition of storyline. Umberto Eco's novel is seen here as a hypertextual book.

Keywords: Umberto Eco, mass culture, reader's identity, illustrated book, hipertextual book

Anna Lubińska - absolwentka filologii polskiej oraz informacji naukowej i bibliotekoznawstwa na Wydziale Filologicznym Uniwersytetu Wrocławskiego. Asystent w Zakładzie Teorii i Historii Książki w Instytucie Informacji Naukowej i Bibliotekoznawstwa UWr. Pracuje nad rozprawą doktorską na temat bibliologicznych aspektów twórczości Umberta Eco. Do jej zainteresowań badawczych należą także literatura i kultura popularna oraz marketing książki.

(c) by the author, licensee Łódź University - Łódź University Press, Łódź, Poland. This article is an open access article distributed under the terms and conditions of the Creative Commons Attribution license CC-BY-NC-ND 4.0 (https://creativecommons.org/licenses/by-nc-nd/4.0/) Received: 11.09.2018; verified: 15.04.2021. Accepted: 22.04.2021. 